\title{
Rationales: rejected, imagined and real - provocation, loss of control and extreme mental or emotional disturbance
}

\author{
Vera Bergelson* \\ Rutgers Law School, Rutgers University \\ Correspondence email: verber@law.rutgers.edu
}

\begin{abstract}
What makes intentional killing under provocation less reprehensible than murder? The answer to this question determines the rationale for the law; and the choice of the primary rationale - justificatory or excusatory - determines the scope and fundamental features of the partial defence.

In this article, I attempt to parse through two reforms - one promulgated by the Model Penal Code (MPC), the other by the Law Commission for England and Wales - and compare their versions of the defence both to each other and to the 'loss of self-control' defence of the Coroners and Justice Act 2009 in the hope of determining and appraising the governing rationales for each version of the defence. I conclude that the largely justificatory defence of provocation developed by the Law Commission (and to a lesser degree the 'loss of self-control' defence) is legally and morally preferable to the largely excusatory defence proposed by the MPC.
\end{abstract}

Keywords: justification; excuse; provocation; loss of self-control; extreme mental or emotional disturbance; manslaughter; partial defence.

\section{INTRODUCTION}

The major revisions of the law of homicide proposed by the Law 1 Commission for England and Wales (the Law Commission) ${ }^{1}$ were a response to the perceived inadequacy and injustice of the traditional law and its application. By the time of the launch of the reform, the partial defence of provocation had expanded greatly since it first entered

* Distinguished Professor of Law, Robert E Knowlton Scholar, Rutgers Law School. I am grateful to my research assistant Andrew Hoy for his outstanding research and editorial help.

1 The Law Commission was set up by s 1 of the Law Commissions Act 1965 for the purpose of promoting the reform of the law. 
the statute books in the Homicide Act 1957 (the 1957 Act). ${ }^{2}$ The Law Commission, in a series or Consultation Papers, ${ }^{3}$ commented that the law of provocation no longer had clear boundaries or moral basis; 4 that courts were in disagreement about the scope of the defence; and that legal scholars were highly critical of the defence's logic and moral foundation. 5 These developments have made it necessary to rethink the very essence of the defence.

The most fundamental question the Law Commission had to address involved the rationale for the defence: what makes intentional killing under provocation less reprehensible than murder?6 ${ }^{6}$ Is it the lesser wrongfulness of the provoked killing or the lesser culpability of the provoked killer? If the answer is the former, then provocation is a partial justification; if the latter, it is a partial excuse. In the words of the Law Commission,

The essence of the justificatory basis is that a killing should be regarded as morally less reprehensible than murder where the victim carries responsibility for making the defendant lose his or her temper. The essence of the excusatory basis is that the killing should be regarded as morally less reprehensible than murder where (with or without any blameworthiness on the part of the victim) the defendant was in such a state as not to be able to exercise self-control and therefore not fully responsible for his or her actions. ${ }^{7}$

In its search for the correct rationale, the Law Commission has turned to various sources, including one of the most influential doctrinal projects in criminal law, the Model Penal Code (MPC). The MPC experience was particularly valuable to the Law Commission not only because the MPC drafters in their rethinking of the defence of provocation had dealt with essentially the same issues as the Law Commission half-a-century

2 The Act, at s 3, reads: 'Where on a charge of murder there is evidence on which the jury can find that the person charged was provoked (whether by things done or by things said or by both together) to lose his self-control, the question whether the provocation was enough to make a reasonable man do as he did shall be left to be determined by the jury; and in determining that question, the jury shall take into account everything both done and said according to the effect which, in their opinion, it would have on a reasonable man.'

3 Law Commission, Partial Defences to Murder (Law Com No 173, 2003) 11; Law Commission, Partial Defences to Murder (Law Com No 290, 2004); Law Commission, Murder, Manslaughter and Infanticide (Law Com No 304, 2006).

$4 \quad$ Law Com No 173 (n 3 above) para 1.52; Law Com No 304 (n 3 above) para 1.46 ('the scope of the defence has become unclear'); Law Com No 290 (n 3 above) para 3.21 ('The rationale underlying the defence of provocation is elusive').

5 Law Com No 173 (n 3 above) para 1.21: quoting Lord Hoffman that it is impossible to read even a selection of the extensive modern literature on provocation without coming to the conclusion that the concept has serious logical and moral flaws'.

6 Ibid para 12.5 .

7 Law Com No 173 (n 3 above) para 12.6. 
later, but also because the legislative changes resulting from the MPC reform and their judicial application have revealed the strengths and weaknesses of the MPC choices.

After a profound consideration of the MPC version of provocation conceptualised as the actor's 'extreme mental or emotional disturbance' (EMED), the Law Commission has rejected it. ${ }^{8}$ Instead, the Law Commission proposed to frame provocation as a partial defence to a killing committed in response to either gross provocation which caused the defendant to have a justifiable sense of being seriously wronged or fear of serious violence (or both) ${ }^{9}$

The law, as enacted by the Coroners and Justice Act 2009,10 differed from the Law Commission's proposal in that it replaced the defence of provocation with the defence of 'loss of control' in the circumstances very similar to those recommended by the Law Commission for the defence of provocation but, as the name of the defence suggests, retained the requirement of loss of self-control rejected by the Law Commission. 11

The three approaches - the MPC, the Law Commission's and the 'loss of control' defence of the Coroners and Justice Act 2009 (the latter two, together, the 'UK Reform') - represent different doctrinal visions of the defence. While all three possess some elements of the excusatory and the justificatory rationales, the different balance of these elements makes the meanings of these defences dramatically different.

In this article, I parse through the defences envisioned by the MPC and the Law Commission and compare them to each other and to the Coroners and Justice Act 2009 with the purpose of determining and appraising the governing rationales for each version of the defence - provocation, EMED and loss of control. The comparative analysis serves three main goals: it helps to reveal the moral, logical and structural strengths and weaknesses of the different versions of the defence; it highlights the strong intrinsic presence of the justificatory

8 Law Com No 290 (n 3 above) para 3.59: 'We would not recommend importing a defence based on EMED. We think that it is too vague and indiscriminate.'

$9 \quad$ Law Com No 304 (n 3 above) para 5.11.

10 Coroners and Justice Act 2009, s 54.

11 The Coroners and Justice Act 2009 uses both terms, 'loss of control' and 'loss of self-control', without defining either. See eg Tony Storey, 'Court of Appeal: "sufficient evidence" (again) $R v$ Gurpinar; $R v$ Kojo-Smith [2015] EWCA Crim 178, Court of Appeal' (2015) 79 Journal of Criminal Law 154: 'The phrase [loss of self-control] appears in the CJA 2009 on seven occasions (in s. 54(1)(a) and (b), s, 55(2), (3), (4), (5) and (6)), and the phrase "loss of control" also appears (in s. 54(2)).' Neither 'loss of self-control' nor 'loss of control' is defined anywhere in the legislation. In this article, 'loss of control' is used to refer to the name, while 'loss of self-control' is used to refer to the meaning, of this partial defence in the Coroners and Justice Act 2009. 
component in the defence; and it contributes to the critical assessment of the attempts to reform the defence of provocation in Anglo-American jurisprudence.

\section{WHY DOES THE RATIONALE MATTER?}

Let's begin with an underlying question: why does it matter what should be the rationale for the defence? Whether defined as a partial justification or partial excuse, it does the same job: reduces the highest form of homicide to a lower one. ${ }^{12}$ Why shall we spend any time determining the moral meaning of each version of the defence? ${ }^{13}$ Here is why.

\section{Political reasons}

The reason for exculpation matters because criminal law closely follows societal normative judgments. A criminal sentence is a condemnation of a wrongful act and of the actor who committed the act. Conversely, a criminal defence supplies a conclusive reason for foregoing such condemnation. Just as the court owes an explanation to defendants as to why they deserve punishment, it also owes explanation to society as to why it should not punish a particular defendant despite the fact that the defendant overstepped a valid criminal prohibition. If this explanation goes against the public perceptions of right and wrong often enough, the authority of the criminal law and the criminal justice system is likely to suffer. ${ }^{14}$ If this explanation is unclear, the meaning of the law becomes unclear too. In its Consultation Paper No 290, the Law Commission has acknowledged that one of the major criticisms it has received with respect to the earlier Consultation Paper No 173 was that the "provisional conclusions failed adequately to explain the rationale underlying [the] proposed approach.' 15

12 Under the Law Commission's proposal, the defence would reduce first degree murder to second degree: Law Com No 290 (n 3 above) para 1.13. Under the MPC and the Coroners and Justice Act 2009, the mitigation is from murder to manslaughter. Model Penal Code, s 210.3(1)(b); Coroners and Justice Act 2009, 54(7).

13 See eg Gabriel J Chin, 'Unjustified: the practical irrelevance of the justification/ excuse distinction' (2009) 43 University of Michigan Journal of Law Reform 79.

14 Paul Robinson and John Darley, 'The utility of desert' (1997) 91 Northwestern University Law Review 453, 456; Vera Bergelson, 'Victims and perpetrators: an argument for comparative liability in criminal law' (2005) Buffalo Criminal Law Review 385, 427-432.

15 Law Com No 290 (n 3 above) para 3.62 (emphasis added). 


\section{Moral and communicative reasons}

Justifications and excuses provide morally distinguishable rationales for withholding punishment: justifications focus on the wrongfulness of an act; excuses focus on the culpability of the actor. A partial justification renders the act less wrongful, and a partial excuse renders the actor less blameworthy, compared to the actor's culpability in the absence of the mitigating circumstance. ${ }^{16}$

Accordingly, if we reduce murder to manslaughter on the theory of partial excuse, we wholly condemn the defendants' conduct and merely give them a break because of their reduced volitional or cognitive capacity. In contrast, if we reduce the defendants' offence based on the theory of partial justification, we treat them as fully responsible agents and acknowledge that what they did was to some extent right or at least not entirely wrong because there were adequate reasons that caused them to behave in a certain, normally reprehensible, way.

The message addressed to the defendant and the public at large is important. Consider, for instance, killings committed by battered spouses in non-confrontational settings. If such a killing is to be manslaughter rather than murder, would the reason for the mitigation not say a lot about that society's values, biases and power dynamics? In early cases of this kind, women often relied on the 'battered wives' syndrome and pleaded an excuse based on their cognitive or volitional abnormality. Even when this strategy was successful, its success came at a price: to avoid the pain and stigma of harsh punishment, the woman had to embrace 'another kind of stigma and pain: she [had to] advance an interpretation of her own activity that label[led] it the irrational product of a mental health disorder' ${ }^{17}$ A completely different message is sent by a law, under which evidence of systematic abuse can be used to 'establish the gravity of the wrongdoing and the justifiable sense of being seriously wronged which would have been experienced by any person of normal tolerance and self-restraint.'18

\section{Coherence and consistency}

Identifying the proper reason for exculpation is important for the inherent coherence of the defence and its consistency with other defences and the fundamental principles of criminal law. For example, if the provoked killing is deemed morally less reprehensible than murder because 'the defendant was in such a state as not to be able

16 Douglas N Husak, 'Partial defenses' (1998) 11 Canada Journal of Law and Jurisprudence 167, 170.

17 Anne M Coughlin, 'Excusing women' (1994) 88 California Law Review 1, 7.

18 Alan Norrie, 'The Coroners and Justice Act 2009 - partial defences to murder (1) loss of control' [2010] Criminal Law Review 275, 286 (emphasis added). 
to exercise self-control and therefore not fully responsible for his or her actions',19 then it is not clear why the same logic is not applied to coerced killings committed under duress or any killings committed under the influence of intoxication.

\section{Scope and boundaries}

Finally, the moral basis for the defence determines its scope and boundaries. As the Law Commission has acknowledged, if the moral basis for provocation is justificatory, the scope of the defence would be limited, and the "focus would be on the wrongful conduct of the victim which, by provoking the defendant, "justified" the defendant's outburst which led to the killing'. 20 On the other hand, if the moral basis for the defence is excusatory, the defendant would be able to claim it regardless of the source of the defendant's loss of self-control. As a result, 'the ambit of the defence would be much broader'. ${ }^{21}$

Now, keeping in mind these reasons, let us consider the versions of the partial defence of provocation envisioned by the drafters of the MPC in the middle of the twentieth century in the United States (US) and the Law Commissioners some 50 years later in the United Kingdom. What was the meaning of each version and what did each choice entail?

\section{THE MPC REVISION OF THE PROVOCATION DEFENCE: EMED AS PARTIAL EXCUSE}

By the time of the MPC reform, American states by and large followed the common law version of the defence of provocation, or heat-ofpassion, which reduced murder to manslaughter if the defendant killed under the influence of provocation, and that provocation was such as likely to deprive a reasonable person of self-control. 22 Traditionally, the defence was available when the killing happened in response to a few enumerated triggers: (1) an aggravated assault or battery; (2) mutual combat; (3) a serious crime - chiefly violent or sexual assault committed against a close relative of the defendant; (4) illegal arrest; and (5) sudden discovery of adultery. 23

In many ways, the law of provocation pre-dating the MPC reform in the US was similar to its equivalent in the 1957 Act. Conceptually, it was based on the philosophy of retributivism, and it combined elements

19 Law Com No 173 (n 3 above) para 12.6.

20 Law Com No 290 (n 3 above) para 12.17.

21 Ibid para 12.18.

22 See MPC, s 210.3, cmt S(a).

23 Ibid. 
of partial justification and partial excuse. ${ }^{24}$ The MPC rejected that law and provided an alternative theory of provocation:

Criminal homicide constitutes manslaughter when . . . a homicide which would otherwise be murder is committed under the influence of extreme mental or emotional disturbance for which there is reasonable explanation or excuse. The reasonableness of such explanation or excuse shall be determined from the viewpoint of a person in the actor's situation under the circumstances as he believes them to be. ${ }^{25}$

The MPC has made two significant changes to the prevailing law. Firstly, it removed all common law obstacles to the use of the defence. Under the MPC, there are no limitations involving the source of provocation (human or other); the form of provocation (eg words); the identity of the victim; the defendant's fault in being the initial provoker; the coolingoff time etc. As long as the defendant acted 'under the influence of extreme mental or emotional disturbance for which there is reasonable explanation or excuse', he was entitled to mitigation from murder to manslaughter.

And, secondly, the MPC has introduced a 'potentially radical subjectivity'26 into the determination of reasonableness of such explanation or excuse. This determination is to be made from the viewpoint of a person in the actor's situation under the circumstances as he believes them to be. Such individual circumstances as 'blindness, shock from traumatic injury, and extreme grief are all easily read into the term "situation". 27 Besides, even more idiosyncratic features, such as "exceptionally punctilious sense of personal honor or an abnormally fearful temperament' may also not be 'wholly irrelevant to the ultimate issue of culpability'. 28

Consider an example of a case decided under the law modelled after the MPC. ${ }^{29}$ In People $v$ Sepe, 30 the defendant was convicted of second degree murder for beating his girlfriend to death with a baseball bat after she refused to cancel a large family dinner. At trial, the defendant

24 Vera Bergelson, 'Justification or excuse? Exploring the meaning of provocation' (2009) 42 Texas Tech Law Review 307.

25 MPC, s 210.3(1)(b).

26 Sanford Kadish, 'The Model Penal Code's provocation proposal and its reception in the state legislatures and courts of the United States of America, with comments relating to the partial defenses of diminished responsibility and imperfect self defense' in Law Com No 290 (n 3 above) appendix F, 272.

27 MPC, s 210, cmt at 62.

28 Ibid.

29 New York is among five states (along with Arizona, Arkansas, Connecticut and Kentucky) that adopted the MPC provocation provision almost verbatim, replacing, however, the EMED requirement with 'extreme emotional disturbance' (EED). See Kadish (n 26 above). 
relied on the affirmative defence of extreme emotional disturbance (EED) and presented evidence of long-term depression and anxiety related to financial setbacks to his business as well as the upcoming Easter family dinner. The defendant maintained that he had reached his breaking point and lost control of his actions when his girlfriend had rebuffed his suggestion that they cancel the planned gathering. ${ }^{31}$

The appellate court overruled the jury verdict, reversed the defendant's conviction of murder in the second degree, and reduced it to manslaughter. The court concluded that, based on the weight of the credible evidence, the jury was not justified in concluding that the defendant was not acting under the influence of an EED for which there was a reasonable explanation when he attacked and killed his girlfriend. 32 According to the court, both prongs of the defence were satisfied: the defendant in fact acted under extreme emotional disturbance; and, from the defendant's perspective, there was a reasonable explanation for that disturbance. As proof of the first prong, the court cited the following facts:

With respect to the subjective element, the evidence overwhelmingly demonstrates that the defendant, who was in a fragile mental state, was actually influenced by an extreme emotional disturbance when he attacked Carlucci, with whom he had previously shared a loving relationship. The defendant's assault upon Carlucci was unquestionably brutal, with the defendant striking her repeatedly with an aluminum baseball bat to a point beyond redundancy ... Carlucci was struck a minimum of 18 times, with enough force to cut her fingertip off, fracture her entire skull, and leave her brain matter entirely eviscerated from her skull. Most of her injuries occurred as the defendant continued to strike her while she was already on the ground. In our opinion, as described by the forensic experts, the attack was nothing short of a barbaric frenzy, and thus indicative of the defendant's loss of self-control. 33

The defendant's conduct in the aftermath of the homicide supports the conclusion that he was overtaken by an extreme emotional disturbance when he attacked Carlucci. [T] he defendant made no real effort to conceal his actions, leaving the murder weapon beside Carlucci's body, and leaving physical evidence connecting him to the crime throughout the house. The defendant made no effort to evade capture. ${ }^{34}$

For the second prong, the court called attention to the defendant's history of depression and anxiety; it observed that, in the six months preceding the incident, multiple stressful events had caused the

31 Ibid 76-77.

32 Ibid 92.

33 Ibid 88.

34 Ibid 89. 
defendant's condition to deteriorate and resulted in significant mental trauma and sleep deprivation. 35 The court concluded:

This defendant's unique feeling ... of overwhelming pressure of 'all [his] problems, all [his] stuff,' was compounded by the pressure of having to host 'all these people,' his fear that he couldn't 'talk to all these people' when he 'couldn't talk to one,' and then, albeit innocently, by being asked by his loving companion if he was 'crazy.' We are of the opinion that this defendant did in fact act under an extreme and uncontrived emotional disturbance, for which there was a reasonable explanation. ${ }^{36}$

The Sepe decision demonstrates the dramatic difference between the MPC and the UK Reform versions of provocation. What was a successful defence under the MPC would be unthinkable under the UK Reform for several reasons. First, under the Law Commission's proposal, the defendant has to act under the 'gross provocation' resulting in 'a justifiable sense of being seriously wronged'. ${ }^{37}$ Similarly, under the Coroners and Justice Act 2009, the defendant's loss of self-control has to be attributable to acts or words which 'constituted circumstances of extremely grave character' and caused the defendant to have 'a justifiable sense of being seriously wronged'. 38 Furthermore, under the UK Reform, the defendant's reaction to the provocation has to be evaluated from the perspective of a man of the defendant's age and ordinary tolerance and self-restraint. 39

In Sepe, the victim's refusal to cancel a family dinner party clearly does not rise to the level of a 'serious wrong', not only because of the trivial reason for the quarrel but also because the victim acted within her rights and did not violate any rights of the defendant (or anyone else). Additionally, the defendant's depression, stress and anxiety may not be taken into account as a qualifying trigger under the UK Reform. Under both the Law Commission's proposal and the Coroners and Justice Act 2009, the trigger must be something said or done to the defendant and not just the defendant's personal emotional state. ${ }^{40}$

35 Ibid 90.

36 Ibid 91.

37 See Law Com No 304 (n 3 above) para 5.11.

38 Coroners and Justice Act 2009, s 55(4).

39 Law Com No 304 (n 3 above) paras 5.33-5.46. The Consultation Paper explains that individuals incapable of normal self-restraint due to a 'recognized medical condition' should invoke the defence of diminished responsibility instead. Ibid. 5.42 and 86 (fn 35); Coroners and Justice Act 2009, s 54 (1)(c) (the defence is available only if 'a person of D's sex and age, with a normal degree of tolerance and self-restraint and in the circumstances of $\mathrm{D}$, might have reacted in the same or in a similar way to D').

40 See Law Com No 304 (n 3 above) para 5.11 (requiring 'words or conduct or a combination of words and conduct') and Coroners and Justice Act 2009, s 55(4) (requiring that 'D's loss of self-control [be] attributable to a thing or things done or said (or both)'). 
The two different outcomes - under the MPC and the UK Reform - are a function of two different models of the defence of provocation. The MPC's model is firmly grounded in the rationale of excuse, ${ }^{41}$ although it would be simplification to say that it lacks any elements of justification. Despite the rather extreme subjectivity of its 'reasonable person' test, the EMED defence in the end requires the jury to evaluate the defendant's condition objectively. ${ }^{42}$ Objective reasonableness is an element of justification, not excuse (it would be silly to talk about a 'reasonably insane' or 'reasonably intoxicated' person). However, on the whole, the balance of the excusatory and justificatory elements in the MPC version of provocation is heavily skewed in favour of excuse, which is not surprising considering the overarching utilitarian philosophy of the MPC with its main objective 'to deter criminal conduct and, in the event this failed, to diagnose the correctional and incapacitative needs of each offender' ${ }^{43}$ Focused primarily on pragmatic goals, the MPC drafters understood the defence of provocation as 'a concession to human weakness and perhaps to non-deterrability'. ${ }^{4}$

One strong example of the excusatory meaning of provocation under the MPC is the MPC's rejection of the doctrine of 'misdirected retaliation' which denies mitigation from murder to manslaughter in cases in which the victim did nothing to provoke the attack. 45 The MPC commentary explains that the perpetrator's emotional distress does not have to arise from some 'injury, affront, or other provocative act' attributable to the deceased. Anyone or anything can bring about the defendant's EMED. A person in the condition of EMED is not as deterrable as a rational agent to whom the law directs its commands;

41 Law Com No 290 (n 3 above) para 3.51: 'The defence is rooted in the excuse based category of defences, founded on the defendant's state of mind (whatever may have caused it).'

42 MPC, s 210.3, cmt 3 at 50: 'The ultimate test, however, is objective; there must be "reasonable" explanation or excuse for the actor's disturbance.'

43 Paul H Robinson and Markus D Dubber, 'The American Model Penal Code: a brief overview' (2007) 10 New Criminal Law Review 319, 325. Yet, it has been pointed out that Herbert Wechsler, the primary author of the MPC reform, despite his own utilitarianism, was mindful that 'no criminal code should drift too radically from the public's sense of wrongful behavior and of degrees of wrongdoing'. See Kent Greenawalt, 'A few reflections on the Model Penal Code commentaries' (2003) 1 Ohio State Journal of Criminal Law 241, 241.

44 MPC, s 210.3, cmt 5(a) at 55.

45 Compare Rollin M Perkins, Perkins on Criminal Law 2nd edn (Foundation Press 1969) 69: if 'one who has received adequate provocation is so enraged that he intentionally vents his wrath upon an innocent bystander, causing his death, he will be guilty of murder'; and MPC, s $210.3 \mathrm{cmt} 5(\mathrm{a})$ : 'By eliminating any reference to provocation in the ordinary sense of improper conduct by the deceased, the MPC avoids arbitrary exclusion of some circumstances that may justify reducing murder to manslaughter.' 
thus it would be pointless and wasteful to spend the full amount of the judicial and correctional resources on such an offender.

For illustration, consider People $v$ Spurlin, in which the defendant killed his wife after an intense argument over their mutual infidelities and then killed their sleeping nine-year-old son. ${ }^{46}$ At trial, the judge gave the jury the 'provocation' instruction for the killing of the defendant's wife but refused to give it for the killing of the child. Was the judge wrong? Under the MPC rule, he certainly would have been. A commentary to the MPC explicitly says that mitigation may be appropriate where the actor 'strikes out in a blinding rage and kills an innocent bystander'. ${ }^{47}$

From the perspective of the excusatory rationale, the MPC position is fully warranted, and, had the case been tried in an MPC jurisdiction, the Spurlin defendant should have been allowed to plead the defence. Indeed, what can prove his EMED better than a deadly attack directed at an innocent child? And since the judge found sufficient evidence of a 'reasonable explanation or excuse' for the defendant's condition to issue the EMED instruction in the wife's case, logically, the same instruction should have been given in the child's case too. Moreover, had the defendant killed a few more people - his baby daughter, his neighbours, the paramedics, and the police officers who arrived at the scene of the crime - he should have been entitled to the same jury instruction for all these killings. Under the excusatory rationale, it does not matter how many innocent lives the defendant takes. If the reason for the defence is the killer's inability to control his rage, the defence should apply to everyone killed in that rage: 'Once an accused loses his self-control it is unreal to insist that his retaliatory acts be directed only against his provoker. When his reason has been dethroned a man cannot be expected ... "to guide his anger with judgment".'48

The MPC position with respect to EMED is fully consistent with its position with respect to other defences. In the largely utilitarian universe of the MPC, killing an innocent is not forbidden. In fact, under the choice-of-evils defence, ${ }^{49}$ such killing is not even wrongful, provided it has averted killings of more people. A commentary to the MPC explains: 'The life of every individual must be taken in such a case

46 People $v$ Spurlin, 202 Cal Rptr 663, 665 (Ct App 1984). See also People $v$ Verdugo, 236 P 3d 1035, 1061 (Cal 2010), holding that '[t] he provocation which incites the defendant to homicidal conduct in the heat of passion must be caused by the victim, or be conduct reasonably believed by the defendant to have been engaged in by the victim'.

47 MPC, s 210.3, cmt 5 at 61.

48 R S O’Regan, 'Indirect provocation and misdirected retaliation' [1968] Criminal Law Review 319, 323.

MPC, s 3.02. 
to be of equal value and the numerical preponderance in the lives saved compared to those sacrificed surely should establish legal justification for the act.' 50 Similarly, any mass atrocity is excusable under the MPC if the perpetrator was coerced to commit it by the use or threat of violence which a person of reasonable firmness in his situation would have been unable to resist. 51

The EMED provision has not been particularly influential among states. Of the 34 jurisdictions that revised their criminal codes in the post-MPC era, only five have enacted EED defences matching the EMED $^{52}$ and only a dozen more adopted some features of the EMED, but with significant changes. 53 The MPC position on misdirected retaliation has proven to be even more problematic. At least one-half of American jurisdictions explicitly allow the defence only when the homicide is a result of the victim's provocation, 54 but there may be more such jurisdictions (including those describing provocation in the EED terms).55 In Spurlin, for instance, the court admitted that the California Penal Code is silent on the source of provocation.56 Nonetheless, citing common law principles and interpretations of those principles adopted by several other jurisdictions, the court concluded that, for the provocation defence to be available, 'the deceased must be the source of the defendant's rage or passion'. ${ }^{57}$

The moderate success of the MPC in this area of law is understandable. The significant expansion of the defence promulgated by the MPC would inevitably lead to the outcomes that are inconsistent with the prevailing moral and legal norms. After all, in the Anglo-American legal tradition, intentional killing of an innocent non-aggressor is an absolute

$50 \quad$ Ibid s 3.02, cmt 3 at 15 .

51 Ibid s 2.09 .

52 Kadish (n 26 above) 272.

53 The changes included adding the requirement of a provocative act and rejecting the 'actor's situation' language in favour of the general 'reasonableness' standard: Kadish (n 26 above) 272.

54 See Bergelson (n 24) 311-312, fn 30: some states allow mitigation, in addition, if the person killed was mistaken for the provoker or associated with the provoker.

55 See eg State $v$ Stewart, 624 NW 2d 585, 590-591 (Minn 2001). The state statute was based on the MPC. However, the court noted that 'a heat of passion that provokes an assailant to kill the provocateur will not necessarily satisfy the subjective or objective elements of heat-of-passion manslaughter as to other victims' and concluded that the situation at bar was such a case. Ibid. People $v$ Spurlin, 202 Cal Rptr 663 (Ct App 1984).

57 Ibid. 
taboo. 58 In the famous case of Regina $v$ Dudley and Stephens, two starving men, after many days in a lifeboat without food, killed a boy to save their lives by feeding on his flesh. ${ }^{59}$ At trial for murder, they raised necessity as their defence. Despite the empathy for 'how terrible the temptation was; how awful the suffering', the court found them guilty of murder saying that there was no defence to taking the life of an innocent unoffending person. 60 The Dudley and Stephens holding is still good law on both sides of the Atlantic. Similarly, in the vast majority of common law jurisdictions, duress does not exonerate ${ }^{61}$ or even mitigate ${ }^{62}$ the intentional killing of an innocent. Nor are people justified in defending themselves against a deadly attack if, while doing so, they have to kill not only the offender but also an innocent bystander. ${ }^{63}$ These legal rules are inherently interconnected as they are rooted in the same deontological principle that forbids certain harmful, exploitive and demeaning acts regardless of their beneficial consequences. 64

In sum, the defence of EMED is predominantly grounded in the excusatory rationale. In the closed universe of the MPC, this defence is doctrinally consistent with the general MPC goals and structure. However, in a broader moral and legal universe, the defence of EMED is in conflict with important values and principles governing AngloAmerican criminal jurisprudence.

\section{THE UK REFORM: PARTIAL JUSTIFICATION OR PARTIAL EXCUSE?}

In contrast to the largely utilitarian philosophy of the MPC, the UK Reform has put individual blameworthiness in the foundation of

58 The closest a common law court has ever come to breaking this taboo is $\operatorname{Re} A$ (Children) [2001] Fam 147, in which an English court authorised surgical separation of two conjoined twins which was likely to save the life of one twin but practically certain to kill the other. The case has inspired a lot of soul-searching and debate regarding the role of courts in resolving complicated moral dilemmas. See eg John Fitzpatrick, 'Jodie and Mary: whose choice was it anyway?' (Spiked Liberties, 19 June 2001).

$59 R v$ Dudley [1884] 14 QBD 273, 273-274, reprinted in (1881-1885] All ER Rep 61.

60 Ibid.

61 American Jurisprudence 2nd edn (2020) vol 40, s 107: 'It is generally held that neither duress, coercion, nor compulsion are defenses to murder.'

62 Ibid, stating that duress does not mitigate murder to manslaughter.

63 See eg Larry Alexander, 'Propter honoris respectum: a unified excuse or preemptive self protection' (1999) 74 Notre Dame Law Review 1475, 1482, noting that the law will not allow one to employ deadly force to save himself if doing so will cause the death of an innocent third party.

64 See Larry Alexander, 'Deontological ethics' (Stanford Encyclopedia of Philosophy, 17 October 2016). 
the defence of provocation. Rejecting the MPC approach, the Law Commission explained:

We favour as the moral basis for retaining a defence of provocation that the defendant had legitimate ground to feel seriously wronged by the person at whom his or her conduct was aimed, and that this lessened the moral culpability of the defendant reacting to that outrage in the way that he or she did. 65

This explanation strongly indicates preference for the justificatory rationale for the defence. To see that, compare this excerpt with another one, quoted at the beginning of this article, in which the Law Commission explains to its consultees the meaning of the justificatory rationale: 'The essence of the justificatory basis is that a killing should be regarded as morally less reprehensible than murder where the victim carries responsibility for making the defendant lose his or her temper.'66

The two quotes are almost identical, and yet, the Law Commission has shied away from admitting its reliance on the justificatory rationale for the proposed defence, saying instead: 'It is the justification of the sense of outrage which provides a partial excuse for their responsive conduct.'67 This message is uncomfortably confusing: why would a justification provide an excuse? The two categories - justification and excuse - traditionally have been viewed as mutually exclusive: 'a defendant cannot both be excused and justified because an excused action presupposes that the action was wrong and therefore unjustified'.68

It is possible that, in identifying the nature of the defence of provocation, the Law Commission has relied on the views of Victoria Nourse ${ }^{69}$ whose work it cites extensively. Nourse has argued that we must distinguish between acts (which may be wrong, unjustified) and emotions (which may be warranted and justified). ${ }^{0}$ For example, 'we may easily say that passionate killings are not justified even if we believe that the emotions causing some killings are, in some sense, the "right" emotion'. 71

65 Law Com No 290 (n 3 above) para 3.59.

66 Law Com No 173 (n 3 above) para 12.6.

67 Law Com No 290 (n 3 above) para 3.59.

68 Victoria Nourse, 'Passion's progress: model law reform and the provocation defense' (1997) 106 Yale Law Journal 1331, 1394.

69 Law Com No 290 (n 3 above) paras 3.52 and 3.59, favourably quoting Nourse's view that provocation provides 'a partial excuse (but not a justification) for the defendant's over-reactive response' and almost verbatim repeating same view in the Law Commission's recommendations.

70 Ibid.

71 Ibid. 
I agree that we should distinguish acts and emotions; I doubt, however, that this distinction has the normative force Nourse has envisioned. If the passionate killing is merely excused, then what matters is the magnitude of the defendant's cognitive or volitional impairment, not whether the defendant's emotions are 'justified'. Moreover, it is less than clear how the concept of justifiability should apply to human emotions - and to what emotions, because it is necessary to differentiate between the immediate emotional response (eg anger), which is essentially uncontrollable and thus cannot be either justified or unjustified, and the consequences of this emotional response, such as loss of self-control. Only the latter is an element of the defence of provocation. ${ }^{72}$ But one's loss of self-control is a poor candidate for justification either. As Richard Holton and Stephen Shute have persuasively argued,

Either one thinks of [loss of one's self-control] as something that one does, in which case it is surely not justified. Or one thinks of it as something that just happens to one, in which case talk of it being either justified or unjustified is inappropriate (as one is neither justified, nor unjustified, in sneezing). And this surely entails that if the truth is somewhere between the two models - if losing one's self-control is something that happens to one, but that one could, with sufficient effort, resist - then we should not think that it is ever justified. ${ }^{73}$

Furthermore, the loss of self-control may be produced by an emotion that is not 'right' or 'justified' in any way (eg anger or jealousy based on a mistaken perception of facts). Think of Othello and Desdemona. If the defence of provocation were only a (partial) excuse, then Othello should be entitled to it - as in fact, he would be under the MPC. In contrast, the Law Commission has emphatically denied Othello any mitigation and concluded instead that he should be 'guilty of murder, even if Iago's insinuations had been true'.74 This is not an excusatory conclusion, and it shows that (with or without Nourse's influence) the Law Commission may have mischaracterised its proposed defence.

The Law Commission's struggle with explaining the rationale for provocation goes through the entire project. 75 On the one hand, the Law Commission sees this rationale in the lessened moral culpability of the defendant due to the wrongdoing committed by the provoker;

72 Richard Holton and Stephen Shute (2007) 'Self-control in the modern provocation defence' 27(1) Oxford Journal of Legal Studies 49, 70-71.

73 Ibid 70.

74 Law Com No 290 (n 3 above) para 3.145.

75 One possible explanation for this lack of clarity is an intentional ambiguity chosen by the Law Commission in view of the divided responses of the consultees regarding the proper rationale for the defence. In addition, 'a good number of respondents were unhappy with [the Law Commission's] use of the labels justificatory and excusatory.' See Law Com No 290 (n 3 above) para 3.23. 
on the other, it suggests that 'provocation' may be a misleading name for the defence because it 'implies blameworthiness on the part of the provoker' ${ }^{76}$ On the one hand, it underscores the elements typical for justifications (recall the Law Commission's position regarding Othello's killing of Desdemona); on the other, in those rare instances in which it refers to the defence by name, the Law Commission calls it a partial excuse. ${ }^{77}$

The view of provocation as a partial excuse certainly has a long history. At the time of the 1957 Act, 'there was theoretically an excusatory rationale of sorts, namely that the defendant had suddenly and temporarily lost his or her self-control as a result of provocation which might have caused a reasonable person to do the same'.78 However, as the Law Commission acknowledged, 'this rationale did not bear too close scrutiny'. 79

The excusatory explanation of provocation has also long dominated academic discourse.80 The adherents of this view have argued that society puts too high a value on human life to justify, even partially, an intentional killing of a mere wrongdoer. ${ }^{81}$ This explanation, however, is not entirely compelling. The law often takes the decedent's wrongful or harmful acts into account in reducing or eliminating the killer's punishment: the law of self-defence fully justifies killing of aggressors, even 'innocent aggressors'; assisted suicide is treated as a lesser offence than murder; the victim's consent to, or participation in, the homicide

76 Law Com No 173, para 12.18.

77 See eg Law Com No 290 (n 3 above) para 3.59: 'It is the justification of the sense of outrage which provides a partial excuse for their responsive conduct'; see also ibid para 3.63, explaining exclusion of situations when the defendant's response was considered because there are 'strong policy reasons for the law not to treat vendettas as partial excuses' (emphasis added).

78 Law Com No 290 (n 3 above) para 3.21.

79 Ibid.

80 See eg Joshua Dressler, 'Provocation, explaining and justifying the defense in partial excuse, loss of self-control terms' in Paul Robinson, Kimberly Ferzan and Stephen Garvey (eds), Criminal Law Conversations (Oxford University Press 2009); C Lee, 'Reasonable provocation and self-defence: recognizing the distinction between act reasonableness and emotion reasonableness' in ibid 427; Joshua Dressler, 'Rethinking heat of passion: a defense in search of a rationale' (1982) 73 Journal of Criminal Law and Criminology 421, 442; Markus Dirk Dubber, 'The victim in American penal law: a systematic overview (1999) 3 Buffalo Criminal Law Review 3, 11; Reid Griffith Fontaine, 'Adequate (non) provocation and heat of passion as excuse not justification' (2009) 43 University of Michigan Journal of Law Reform 27.

81 See eg Dressler, Rethinking heat of passion' (n 80) 458; see also Suzanne Uniacke, Permissible Killing: The Self-Defense Justification of Homicide (Cambridge University Press 1996) 13, rejecting justificatory rationale of provocation and criticising Dressler for 'conced[ing] too much to the claim that provocation functions as a partial justification'. 
is a mitigating factor for the purposes of capital punishment in the majority of the US death penalty jurisdictions. ${ }^{82}$ Likewise, the high value assigned to human life should not by itself defeat the justificatory rationale for the defence of provocation.

A different widely shared reason to deny provocation its justificatory rationale lies in the reluctance to 'blame the victim' for the victim's own death. Consider the following argument:

If provocation were a justification, a provoked act would be the right thing to do in the circumstances, or at least (given that provocation does not completely exonerate) more right than wrong. If provocation were a justification, the law would, in effect, be saying that homicidal violence was right - whether the victim was an abused spouse, a person who made a homosexual advance, or someone who insulted the accused in a bar. Provocation would blame victims. If that were provocation's meaning and effect, it would not belong in our criminal law. 83

This argument reveals a serious misconception, a belief that a partial justification may be successful only if the harmful conduct is 'the right thing to do in the circumstances' or at least 'more right than wrong'. This is a misconception because those are requirements of a complete, not partial, justification. Unlike complete justification (eg self-defence), partial justification does not make a killing 'right' or acceptable; it merely makes it 'less wrong' compared to what it would have been without provocation. Even with partial justification, the killing remains wrongful and punishable.

Finally, a defence does not have to be based on a single underlying principle. A product of historical tradition, political compromise and changing cultural norms, the law often combines elements of more than one rationale. Provocation unquestionably includes elements of excuse. It is only available to a person who, temporarily, is not capable of acting fully rationally. ${ }^{84}$ However, for all the reasons cited above, 85 it is important to acknowledge that excuse is not the only rationale for this defence. Indeed, regardless of the Law Commission's characterisation, the version of the provocation defence advocated by the Law Commission is based predominantly on the justificatory rationale. Its justificatory character is underscored by the following features.

82 See Bergelson (n 14 above) 120-121, 153-155.

83 W N Renke, 'Calm like a bomb: an assessment of the partial defence of provocation' (2009-2010) 47 Alta Law Review 729, 750.

84 See Law Com No 304 (n 3 above) para 5.11(3) at 79: the defence is not available to the defendant who 'acted in considered desire for revenge' (emphasis added). See above under the heading 'Why does the rationale matter?'. 
First and foremost, the Law Commission has eliminated the traditional requirement of loss of self-control. ${ }^{86}$ Naturally, the defence is not available if the defendant acts in bad faith (inciting provocation for the purpose of killing the provoker) or in 'considered desire for revenge'; 87 but in all other circumstances, the defence may be invoked by the killer even in the absence of any cognitive or volitional impairment typical for excuses. This feature alone is a clear indication of a strong justificatory component of the defence.

Secondly, while acknowledging that granting a defence for acting in anger may be ethically problematic, the Law Commission nevertheless concluded that 'a killing in anger produced by serious wrongdoing is ethically less wicked, and therefore deserving of a lesser punishment, than say, a killing out of greed, lust, jealousy or for political reasons' ${ }^{88}$ Reasons for action belong to the sphere of wrongdoing, not culpability. To mitigate a wrongdoing, the defendant needs to establish a partial justification; partial excuses mitigate only culpability. Had the Law Commission envisioned the defence as a mere excuse, the reasons for killing would have been immaterial.

Thirdly, the defence is available only for responsive actions 89 of the defendant caused by some grossly provocative words or conduct. The italicised words emphasise the defendant's reduced responsibility for the ultimate wrongdoing.

As a matter of causation, responsive conduct carries little weight and often does not break the chain of causation leaving the original wrongdoer responsible for all the ensuing harm. ${ }^{90}$ For example, when a woman, in response to a sexual assault, had taken poison and later died, the court held the defendant guilty not only of the sexual crimes but also of murder. ${ }^{91}$ Describing the rule in general, Joshua Dressler has commented: 'This outcome is justifiable. The defendant's initial wrongdoing caused the response. Since he is responsible for the

86 Law Com No 290 (n 3 above) para 3.20: 'The concept of loss of self-control has proved to be very troublesome. The supposed requirement of a sudden and temporary loss of self-control has given rise to serious problems, especially in the "slow burn" type of case.'

87 Law Com No 304 (n 3 above) para 5.11(3) at 79.

88 Law Com No 290 (n 3 above) para 3.38.

89 Law Com No 304 (n 3 above) para 5.11 (1)(a) at 78: 'the defendant acted in response to gross provocation or fear'.

90 H L A Hart and Tony Honore, Causation in the Law 2nd edn (Oxford University Press 1985) 149: 'When defendant's conduct causes panic an act done under the influence of panic or extreme fear will not negative causal connection unless the reaction is wholly abnormal.'

91 Stephenson $v$ State, 179 NE 633 (In 1932). 
presence of the intervening force, the defendant should not escape liability unless the intervening force was bizarre and unforeseeable.'92

The Law Commission's proposal explicitly includes the causative element: the defence is available when the grossly provocative words or conduct caused the defendant to feel seriously wronged. ${ }^{93}$ Naturally, in cases of provocation, the provoker is not the only (or the main) cause of the killing. Using Dressler's words, the provoker is 'responsible for the presence of the intervening force', but the provoker cannot be said to have unilaterally caused the defendant's actions - the defendant is an autonomous human being - thus the defence is only partial.

In addition, reactive actions are less wrongful than independent ones. They are less wrongful because the provoker carries partial responsibility for the resulting harm. Harm is an element of wrongdoing; not culpability. Only justifications, not excuses, have the power to affect one's wrongdoing. The Law Commission's proposal affords the defence only when the ultimate harm falls on the provoker (not an innocent bystander), 94 in other words, when the defendant is not solely responsible for the harm. The resulting mitigation of the defendant's wrongdoing is a clear indication of a partial justification at work.

Furthermore, the Law Commission's proposal explicitly limits the defence to the situations when the defendants acted because they had a justifiable sense of being seriously wronged.95 The justifiability of the sense of being seriously wronged is to be determined by the jury from the objective perspective, in addition to the defendant's subjective perception. 96 Had the defence been only excusatory, it should have been available to any defendant who honestly, albeit unreasonably, felt seriously wronged.

The Law Commission sees the moral basis for the defence in that 'the defendant had a legitimate ground to feel strongly aggrieved at the conduct of the person at whom his/her response was aimed'.97 As

92 Joshua Dressler, Understanding Criminal Law 8th edn (Carolina Academic Press 2018) 182.

93 Law Com No 290 (n 3 above) para 3.69 at 46: 'the words or conduct should have caused the defendant to have a sense of being seriously wronged and therefore to react as he or she did'.

94 Ibid para 3.72: 'Except in [cases of mistake or accident], we are satisfied that where $\mathrm{D}$ kills $\mathrm{V}$ in response to provocation by a third party the objective test would preclude this defence. No person of ordinary tolerance and self-restraint would deliberately respond to provocation from one person by using violence to another.'

95 Law Com No 304 (n 3 above) para 5.11(1)(a)(i) at 78.

96 Law Com No 290 (n 3 above) para 3.70: 'we do not intend the test to be purely subjective, i.e. what the defendant thought'.

97 Ibid para 3.68 (emphasis added). 
an example, one consultation paper cites the following hypothetical authored by Jeremy Horder: suppose the defendant holds a strong racist belief that it is a grave offence for a Black person to speak to a White man unless spoken to first, and suppose the defendant became enraged and killed a Black person for speaking to him in this way - is the jury to be directed to take his beliefs into account in judging the gravity of the provocation?98 Horder demands: 'Would not such a direction be an outrageous compromise of society's commitment to racial tolerance?', and the Law Commission emphatically agrees with Horder.99 This is important because the evaluation of what is 'a legitimate ground to feel strongly aggrieved' is conducted from the viewpoint of societal values, to the full exclusion of the defendant's own viewpoint, which once again strongly supports the justificatory, rather than excusatory, rationale for the Law Commission's defence of provocation.

Fourthly, the Law Commission has expanded the traditional defence of provocation by making it available in response not only to gross provocation but also to 'fear of serious violence toward the defendant or another'. 100 The expansion was dictated by the recognised need to make the defence available to victims of abuse who kill their abusers in non-confrontational circumstances. ${ }^{101}$ This new reason behind the defendant's actions has moved the defence closer to the realm of selfdefence and defence of others, the ultimate defences of justification. The Law Commission commented on the link between the two defences, saying that, under the proposed rules, the defendant would have a choice between self-defence and provocation: 'If D is not so confident that the jury will find his or her actions to have been fully justified, he or she can plead provocation - in the form of a fear of serious violence - instead of or alongside a plea of self-defence.'102 The very wording hints that the proposed defence of provocation, unlike self-defence, which is a complete justification, is merely a partial justification, but justification nevertheless.

98 Jeremy Horder, Provocation and Responsibility (Clarendon Press 1992) 144.

99 Law Com No 290 (n 3 above) paras 3.70, 3.71: 'Our answer to the question posed in the last sentence is yes. No fair-minded jury, properly directed, could conclude that it was gross provocation for a person of one colour to speak to a person of a different colour. In such a case the proper course would therefore be for the judge to withdraw provocation from the jury.'

100 Law Com No 304 (n 3 above) para 5.11(1)(a)(ii) at 78.

101 Susan S M Edwards, 'Loss of self-control: when his anger is worth more than her fear' in Alan Reed (ed), Loss of Control and Diminished Responsibility: Domestic, Comparative and International Perspectives (Routledge 2016) 79: 'Recognition in law of the fearful state of mind is intended to bring women who kill violent partners within law's ambit and mercy and so correct a habituated historic injustice.'

102 Law Com No 304 (n 3 above) para 5.56 (emphasis added). 
Finally, even though the Law Commission has not explicitly excluded killings done upon discovery of sexual infidelity from the protection of the defence (that was done in the Coroners and Justice Act 2009 upon the Government's initiative), 103 it was critical of treating sexual infidelity as a qualifying 'wrongdoing' giving rise to the defence. This position would make little sense had the Commission seen the rationale for the defence as merely excusatory. As an evidentiary matter, the discovery of sexual infidelity can certainly produce strong feelings of betrayal and resentment and can lead to one's loss of self-control and rash violent outbreak. ${ }^{104}$

In sum, the provocation defence proposed by the Law Commission had a predominantly justificatory character.

\section{THE ADVANTAGES OF THE UK REFORM OVER THE EMED}

\section{The Law Commission's proposal versus the EMED standard}

Compared to the EMED promulgated by the MPC, the defence of provocation proposed by the Law Commission had several important advantages.

\section{Public perceptions of right and wrong}

Unlike the largely utilitarian, almost exclusively excusatory EMED model, which went against many established moral norms and expectations, 105 the Law Commission's proposal proved to be in accord with the public perceptions of justice and fair play. Numerous interviews with individuals representing 'a wide cross-section of backgrounds and personal circumstances'106 have shown that there 'appears to be widespread recognition that provocation mitigates the

103 Coroners and Justice Act 2009, s 55(6)(c); see also, Ministry of Justice, Murder, Manslaughter and Infanticide: Proposals for Reform of the Law (CP No 19/08, 2008) para 2.

104 Oliver Quick and Celia Wells, 'Partial reform of partial defences: development in England and Wales' (2012) 45 Journal of Criminology 337, 344: 'The sexual infidelity clause (now s 55(6)(c)) was added during the Bill's passage through Parliament and was not subject to any meaningful public consultation (Horder, 2012). This is a controversial aspect of the new law, but perhaps unsurprising given the background view that sexual jealousy should not be a legitimate reason to plead provocation.'

105 See above, discussion at the end of the section entitled 'The MPC revision of the provocation defence: EMED as partial excuse'.

106 Barry Mitchell, 'Brief empirical survey of public opinion relating to partial defences to murder' in Law Com No 290 (n 3 above) appendix C, 180. 
seriousness of a homicide; respondents commonly expressed sympathy and empathy for those who react emotionally to a stimulus, either through anger or fear or (cumulative) stress'.107 The fact that the sympathy and empathy were expressed with respect to those who were somehow wronged suggests that the interviewed individuals viewed the element of 'provocation' as morally significant. Characteristically, almost all consultees welcomed the extension of provocation to cover cases in which the killing was motivated by a fear of serious violence. ${ }^{108}$

\section{Coherence and consistency}

Even though the philosophy of EMED is very much in accord with the general philosophy of the MPC, from a larger perspective, the mostly justificatory provocation proposed by the Law Commission is more consistent with other criminal law doctrines (particularly other defences) than the largely excusatory EMED proposal. Just like the doctrines of consent and self-defence, the doctrine of provocation recognises the active role of the putative victim in reduction of the defendant's wrongdoing. As a matter of autonomy - both the defendant's and the victim's - this vision of the partial defence is more consistent with the criminal law philosophy than the unilateral, excusatory, 'medicalised' version of the MPC, which focuses merely on the defendant's emotional or mental disability and ignores the victim's partial responsibility for the ultimate harm.

\section{Narrowing the scope of the defence}

Mitigation from murder to manslaughter due to provocation has long been perceived as morally controversial. ${ }^{109}$ There has been considerable movement for the abolition of the defence. ${ }^{110}$ In this regard, a narrower version of the defence is preferable to a broader one. The provocation defence proposed by the Law Commission is significantly narrower than the open-ended EMED promulgated by the MPC.

\section{Normativity}

The Law Commission's version of the defence is available only if 'a person of the defendant's age and of ordinary temperament' in the defendant's circumstances might have reacted in the same or similar way. This standard is much more objective than the extremely individualised

107 Ibid 195.

108 Law Com No 304 (n 3 above) para 5.60.

109 See eg Vincent McAviney, 'Coroners and Justice Act 2009: replacing provocation with loss of control' (Inherently Human, 28 October 2010): 'Instead of trying to differentiate between acceptable and non-acceptable murders we should simply make a stand and say that it is never an appropriate response to getting angry.'

110 Law Com No 290 (n 3 above) paras 3.36, 3.44. 
'reasonable person' standard of the MPC under which the facts, to a large extent, have to be seen from the defendant's perspective (recall People $v$ Sepe). One consultation paper explains the difference:

The test under our proposal is not whether the defendant's conduct was reasonable, but whether it was conduct which a person of ordinary temperament might have been driven to commit (not a bigot or a person with an unusually short fuse). We believe that a jury would be able to grasp and apply this idea in a common-sense way. ${ }^{111}$

By organising the defence this way, the Law Commission avoids the "chief dangers of the Model Penal Code approach [such as] its extreme individualization of the "reasonable person" test and its willingness to abandon or cloak moral assessments in favor of sympathy for a defendant's purported volitional impairment'.112

\section{Clarity}

The Law Commission's formulation of the defence is more precise than the MPC's. ${ }^{113}$ To a large degree, this is achieved 'by introducing a robust, objective test based on the person of ordinary tolerance and selfrestraint as a controlling mechanism', which reduces 'the possibility of the reformulation being used to extend the partial defence beyond its proper boundaries'.114

\section{The effect of the changes brought in by the Coroners and Justice Act 2009}

The Coroners and Justice Act 2009 has adopted most of the proposals made by the Law Commission - with a few changes. 115 The most important among those changes was the retention of the loss of self-control requirement advocated by the Government in spite of the strong opposition by the Law Commission which described that requirement as 'a judicially invented concept, lacking sharpness or a clear foundation in psychology'. 116 The 'government was worried that

111 Ibid para 3.127 (emphasis added).

112 Carolyn B Ramsey, 'Provoking change: comparative insights on feminist homicide law reform' (2010) 100 Journal of Criminal Law and Criminology 55, 84-85.

113 A majority of judges and academics who responded to the Law Commission's consultations query were opposed to a test of extreme emotional disturbance, principally on the ground that it was too vague: see Law Com No 290 (n 3 above) para 3.49.

114 Ibid para 4.26 .

115 In addition to the loss of self-control, other notable changes are: (i) further individualisation of the standard of a person with a 'normal degree of tolerance and self-restraint' to include the defendant's sex (Coroners and Justice Act 2009, s 54(1)(c)); and (ii) explicit exclusion of sexual infidelity as an available trigger (Coroners and Justice Act 2009, s 55.6(c)).

116 Law Com No 290 (n 3 above) para 3.30. 
without it there would be a real risk of undeserving cases - such as honour killings, gang-related homicides, and some battered spouse cases - continuing to benefit from the partial defence'. ${ }^{117}$ The Law Commission, on the other hand, was opposed to it because of its moral ambiguity 118 and its built-in bias 'privileging men's typical reactions to provocation over women's typical reactions'.119

The addition of the loss of self-control requirement (albeit without its 'suddenness' component embodied in the law before the Coroners and Justice Act 2009) ${ }^{120}$ has certainly increased the excusatory component of the new defence but has not changed the overall justificatory character of its rationale. As Jonathan Herring has correctly pointed out, the role of the loss of self-control requirement in the Coroners and Justice Act 2009 is 'essentially exclusionary, rather than carrying moral weight as the basis of the defence'. This requirement is intended to exclude those acting out of revenge or in a cold-blooded way, 'rather than being central to the philosophical basis for the defence'. 121

The requirement of loss of self-control has proven to be a controversial addition, particularly in two respects - its fairness (including public perceptions of right and wrong) and clarity.

Interviews with representatives of different demographic groups have shown that loss of self-control is not considered a morally important criterion. ${ }^{122}$ Moreover, as a practical matter, a significant number of respondents, 'including particularly representative bodies

117 Barry Mitchell, 'Loss of self-control under the Coroners and Justice Act 2009: Oh No!' in Reed (n 101 above) 44.

118 A consultation paper observed: 'To ask whether a person could have exercised self-control is to pose an impossible moral question. It is not a question which a psychiatrist could address as a matter of medical science, although a noteworthy issue which emerged from our discussions with psychiatrists was that those who give vent to anger by "losing self-control" to the point of killing another person generally do so in circumstances in which they can afford to do so.' See Law Com No 290 (n 3 above) para 3.28.

119 Law Com No 304 (n 3 above) para 5.18.

120 Coroners and Justice Act 2009, s 54(2): '[f] or the purposes of subsection (1)(a), it does not matter whether or not the loss of control was sudden'.

121 Jonathan Herring, 'The serious wrong of domestic abuse and the loss of control defence' in Reed (n 101 above) 67.

122 See eg Barry Mitchell, 'Brief empirical survey of public opinion relating to partial defences to murder' in Law Com No 290 (n 3 above) appendix C, 195-196. Similarly, courts have rejected the argument that a reasonable person who has lost self-control cannot be fully responsible for his conduct. For example, in Phillips $v$ The Queen [1969] 2 AC 130, Lord Diplock criticised as empirically wrong the premise that 'loss of self-control is not a matter of degree but is absolute; there is no intermediate stage between icy detachment and going berserk'. 
of the legal profession, women's groups and JUSTICE', preferred the morally imperfect EED test to a test based on loss of self-control.123

Many scholars have also commented on the unfairness of applying the loss of self-control requirement to situations where fear is the trigger. ${ }^{124}$ Susan S M Edwards has pinpointed the issue:

The abused woman who kills out of fear, with all its despair, hopelessness, sorrow, helplessness, anguish and trauma, is still required to 'lose selfcontrol' (s 54). And perhaps there is a loss of control but in desperation. But the legal template of loss of self-control s 55(4)(a)(b) remains soldered to a male angered reaction with its outward demonstration embedded in a legacy of 'serious wrongs' and 'justifiable' hubris. ${ }^{125}$

As far as the concern about clarity, the loss of self-control standard has been criticised as ambiguous and confusing. ${ }^{126}$ Firstly, there is no definition of 'loss of control' (or 'loss of self-control') in the Coroners and Justice Act 2009,127 and courts have interpreted that requirement differently. Compare, for instance, $R v$ Jewell, in which the loss of selfcontrol was held to mean a loss of the ability to act in accordance with considered judgment or loss of normal powers of reasoning, ${ }^{128}$ with $R$ $v$ Dawes, in which the 'loss of self-control' jury instruction was denied because the defendant had not killed the victim 'in a rage'; he was 'shocked rather than angry'.129 In addition, as Nicola Wake has accurately observed, 'the government's decision to qualify the "fear trigger" with the controversial "loss of self-control" conceptualisation has undermined the doctrinal coherence in the Law Commission's recommendations, rendering the partial defence "unnecessarily complex". 130

In sum, the Coroners and Justice Act 2009 has been a significant improvement compared to the state of the law of provocation prior to its enactment. The impressive work conducted by the Law Commission has provided both theoretical and empirical foundations for the law reform. Despite the questionable necessity for the loss of self-control requirement, the Coroners and Justice Act 2009 has also exhibited important advantages over the EMED defence developed by the MPC, such as its stronger moral connection with public perception of right

123 Law Com No 290 (n 3 above) para 3.49.

124 See eg Susan S M Edwards, 'Recognising the role of the emotion of fear in offences and defences' (2019) 83 Journal of Criminal Law 450.

125 Ibid 468.

126 Law Com No 290 (n 3 above) para 3.28: 'The term loss of self-control is itself ambiguous because it could denote either a failure to exercise self-control or an inability to exercise self-control. See also Storey (n 11 above) 154.

127 Storey (n 11 above) 154.

128 [2014] EWCA Crim 414 [23].

129 [2013] EWCA Crim 322 [64].

130 Nicola Wake, 'Battered women, startled householders and psychological self-defence: Anglo-Australian Perspectives' (2012) 77 Journal of Criminal Law 433, 436. 
and wrong; its coherence and consistency with the overarching criminal law philosophy; its narrower scope; its more objective and principled normativity; and its clarity.

\section{CONCLUSION}

The law of provocation has long been perceived as legally, morally and politically unsatisfactory. Changing that law required rethinking its rationale and developing a coherent theory that would explain why provoked killing is less deserving of punishment than unprovoked. Justification and excuse, the two competing desert-based rationales, are often present together in a partial defence. The balance of the two rationales, however, significantly determines the meaning and boundaries of the resulting defence. In choosing the rationale for its version of the defence of provocation, each of the MPC and the Coroners and Justice Act 2009 has followed a distinct route.

The MPC has framed its defence as a partial excuse based on the defendant's highly individualised, distraught perception of reality and his inability to act rationally due to a mental or emotional trauma. The EMED defence is inherently consistent with the overarching utilitarian philosophy of the MPC but, at the same time, it is in deep conflict with the overarching deontological moral principles of Anglo-American criminal jurisprudence. It is, thus, not surprising that the Law Commission has rejected the MPC theory. Neither is it surprising that the Law Commission's own theory of provocation, enrooted in the traditional normative morality, should be predominantly justificatory. What is surprising though is the confusion, ambiguity and denial surrounding that choice. The Law Commission's position is uncharacteristically vague and self-contradictory whenever the discussion or recommendations turns to the rationale for the proposed defence.

By critically analysing the essential features of the Law Commission's proposal, I have shown that most of them indicate the reduced wrongfulness of the defendant's act, not the reduced culpability of the defendant, which reveals the predominantly justificatory character of the Law Commission's defence of provocation. Even the addition of the controversial and, arguably, unnecessary 'loss of self-control' requirement in the final version of the defence embodied in the Coroners and Justice Act 2009 has not significantly changed that balance. Overall, the defence of provocation - so unfortunately renamed 'loss of control' - was a significant doctrinal accomplishment, in part because of its salutary choice of the predominantly justificatory rationale. 